\title{
PENGEMBANGAN BAHAN AJAR MATA KULIAH BELAJAR DAN PEMBELAJARAN BERBASIS TRI CIRI TENTARA PELAJAR (PATRIOTISME, KEPELOPORAN DAN KEMANDIRIAN) PADA MAHASISWA UTP SURAKARTA
}

\author{
Ninda Beny Asfuri ${ }^{1}$, Rika Yuni Ambarsari ${ }^{2}$ \\ nindaarjuna@gmail.com ${ }^{1}$, rikaambarsari602@gmail.com ${ }^{2}$ \\ PGSD, FKIP, Universitas Tunas Pembangunan Surakarta ${ }^{1,2}$
}

\begin{abstract}
Abstrak: Bahan ajar merupakan salah satu faktor penting dalam keefektifan sebuah pembelajaran terlebih di tingkat Perguruan Tinggi. Kurangnya bahan ajar tentunya dapat mempengaruhi kualitas pembelajaran atau perkuliahan. Tujuan dari pengembangan modul ini yaitu 1) untuk menambah pemahaman mahasiswa mengenai tri ciri tentara pelajar yang mana akan dikembangkan di dalam mata kuliah belajar pembelajaran sehingga mahasiswa benar-benar menjiwai, memaknai dan bisa mengimplementasikan dalam kehidupan seharihari di kampus dan diluar kampus, 2) untuk mengetahui tingkat kelayakan bahan ajar yang dikembangkan. Jenis penelitian ini adalah penelitian pengembangan atau researh and development. Pengembangan mengacu pada model pengembangan ADDIE (analysis, design, development, impementasi and evaluation). Berdasarkan keseluruhan penilaian produk oleh ahli materi dan pembelajaran diperoleh skor $X=265$, yang termasuk dalam kriteria nilai "Sangat Baik". Sedangkan keseluruhan penilaian produk oleh ahli media diperoleh skor X= 167, yang termasuk dalam kriteria nilai " Sangat Baik".
\end{abstract}

Kata Kunci: pengembangan bahan ajar, belajar dan pembelajaran, Tri Ciri TP.

\section{DEVELOPMENT OF TEACHING MATERIALS BASED ON TRI CHARACTERISTICS OF STUDENT ARMYS (PATRIOTISM, PIONEERING AND INDEPENDENCE) ON STUDENTS OF UTP SURAKARTA}

Abstract: Teaching materials are one of the important factors in the effectiveness of learning,
especially at the Higher Education level. The lack of teaching materials can certainly affect
the quality of learning or lectures. The purpose of developing this module is 1) to increase
students' understanding of the three characteristics of student soldiers which will be
developed in learning courses so that students really animate, interpret and can implement
them in everyday life on campus and outside campus, 2 ) to determine the feasibility level of
the developed teaching materials. This type of research is research and development
research. Development refers to the ADDIE development model (analysis, design,
development, implementation and evaluation). Based on the overall assessment of the
http://ojs.unpkediri.ac.id/pgsd
|Volume $7 \mid$ Nomor $\mathbf{1} \mid$ Juli 2021 
Ninda, Rika. Pengembangan Bahan Ajar Mata...

product by material and learning experts, a score of $X=265$ was obtained, which was included in the "Very Good" score criteria. While the overall product assessment by media experts obtained a score of X=167, which is included in the "Very Good" score criteria.

Keywords: development of teaching materials, learning and learning, Tri Characteristics of $T P$.

\section{PENDAHULUAN}

Bahan ajar merupakan salah satu faktor penting dalam keefektifan sebuah pembelajaran terlebih di tingkat Perguruan Tinggi. Bahan ajar digunakan sebagai salah satu sumber acuan bagi pendidik (dosen) dalam pelaksanaan pembelajaran. (Priyanto dalam Prasetiyo, 2017:20) Kurangnya bahan ajar tentunya dapat mempengaruhi kualitas pembelajaran atau perkuliahan. Dalam buku Pedoman Penulisan Buku Pelajaran (Depdiknas dalam Arsanti, 2018: 72) disebutkan bahwa "yang termasuk isi pendidikan ialah segala sesuatu yang oleh pendidik langsung diberikan kepada peserta didik dan diharapkan untuk dikuasai peserta didik dalam rangka untuk mencapai suatu kompetensi tertentu dalam pendidikan."

Dalam konteks pendidikan di Perguruan Tinggi, khususnya pada mata kuliah Belajar dan Pembelajaran serta berdasarkan visi perguruan Tinggi Universitas Tunas Pembangunan Surakarta (UTP) yaitu menjadi kampus yang berlandaskan Tri Ciri Tentara Pelajar, maka perlu adanya pengembangan buku ajar yang sesuai dengan mata kuliah yang paling penting di FKIP yaitu mata kuliah belajar dan pembelajaran serta mengaitkan ciri khas dan visi kampus Universitas Tunas Pembangunan Surakarta (UTP Surakarta) yaitu Tri Ciri Tentara Pelajar (patriotisme, kepeloporan dan kemandirian). Semboyan yang tidak dimiliki oleh kampus lain, dimana ciri khas tersebut membantu mahasiswa meraih prestasi tinggi diimbangi dengan karakter dan kepribadian yang baik dan kuat sehingga kelak akan menjadi penerus bangsa yang mampu bersaing dan selaras dengan perkembangan zaman.Dengan dikembangkannya mata kuliah belajar dan pembelajaran berbasis Tri Ciri Tentara Pelajar (Patriotisme, Kepeloporan dan Kemandirian) di harapkan mahasiswa lebih menguasai caracara belajar dan mengajar serta memahami,menghayati dan mampu mengaplikasikan belajar dan pembelajaran berbasis Tri Ciri Tentara Pelajar dalam kehidupan sehari-hari dikampus dan diluar kampus UTP.

Berdasarkan hasil wawancara serta observasi selama kegiatan perkuliahan, masih ada beberapa mahasiswa yang belum faham benar mengenai persoalan di dalam belajar dan pembelajaran serta belum benar-benar memahami mengenai Tri Ciri Tentara Pelajar 


\section{Ninda, Rika. Pengembangan Bahan Ajar Mata...}

(patriotisme, kepeloporan dan kemandirian) terlihat pada saat dosen memberi pertanyaan kepada mahasiswa. Hal itu tentunya mempengaruhi keefektifan perkuliahan mata kuliah tersebut. Dalam memenuhi kebutuhan bahan ajar tersebut serta agar mahasiswa lebih memahami dan mampu mengaplikasikan dosen harus menyediakan bahan ajar sendiri sesuai dengan karakteristik mahasiswa dan mata kuliah yang diampu yaitu dengan mengembangkan bahan ajar tersebut. Dengan mahasiswa mampu memahami bahan ajar tersebut diharapkan dapat menjadi salah satu kecakapan hidup (life skill) yang dimiliki mahasiswa yang dapat bermanfaat ketika sudah lulus dan menginjak dunia kerja. Kecakapan hidup tersebut antara lain yaitu kecakapan dalam hal mengajarkan pembelajaran di kelas pada saat nantinya mahasiswa menjadi guru berlandaskan Tri Ciri Tentara Pelajar dengan mengedepankan nilai karakter dengan begitu akan membawa nama baik almamater.

Bahan ajar menurut Depdiknas (dalam Arsanti, 2018: 72) yaitu bahan ajar adalah segala bentuk bahan yang digunakan untuk membantu guru/instruktur dalam melaksanakan kegiatan belajar mengajar di kelas, baik berupa bahan tertulis seperti hand out, buku, modul, lembar kerja mahasiswa, brosur, leaflet, wallchart, maupun bahan tidak tertulis seperti video/film, VCD, radio, kaset, $\mathrm{CD}$ interaktif berbasis komputer dan internet. Bahan ajar dalam bentuk tertulis berupa materi yang harus dipelajari mahasiswa sebagai sarana untuk mencapai standar kompetensi dan kompetensi dasar. Materi pembelajaran tersebut berupa pengetahuan, keterampilan, dan sikap yang harus diajarkan oleh pendidik dan harus dipelajari oleh mahasiswa untuk mencapai standar kompetensi dan kompetensi dasar. Sihotang dan Sibuea (2015:172) mendefinisikan buku ajar sebagai seperangkat substansi pelajaran yang mencakup isi kurikulum yang harus dicapai peserta didik dalam pembelajaran dan disusun secara sistematis sehingga tercipta lingkungan atau suasana yang memungkinkan peserta didik untuk belajar.Untuk itu, materi buku ajar hendaknya bersifat relevan, memuat bahan atau pembahasan yang linear, dan merupakan satu kesatuan yang sistematis (Gultom, 2012).

Kegiatan pembelajaran di perguruan tinggi menekankan bahwa dosen bukan lagi satusatunya sumber belajar di kelas. Dosen lebih diarahkan untuk berperan sebagai fasilitator yang membantu dan mengarahkan mahasiswa dalam belajar. Mahasiswa diarahkan untuk menjadi pembelajar yang aktif dengan membaca atau mempelajari materi yang ada dalam bahan ajar terlebih dahulu sebelum mengikuti perkuliahan. Oleh karena itu, penggunaan bahan ajar menjadi salah satu hal penting dalam kegiatan pembelajaran (Noviyanti, Gading G, 2010: 106). Hal ini karena dalam bahan ajar terdapat bahan pembelajaran yang harus dikaji, dicermati, materi yang akan dipelajari dan dikuasai oleh mahasiswa. Bahan ajar juga dapat dijadikan pedoman untuk mempelajarinya. Tanpa bahan ajar maka pembelajaran tidak 


\section{Ninda, Rika. Pengembangan Bahan Ajar Mata...}

akan berjalan lancar. Bahan ajar yang didesain dengan desain yang menarik dapat menstimulasi mahasiswa untuk belajar dan memanfaatkannya sebagai sumber belajar. Bahan ajar yang didesain secara lengkap dapat berperan sebagai bahan belajar mandiri. (Kurniawati, dkk, 2015: 102)

Karakteristik bahan ajar yang baik menurut Depdiknas (dalam Arsanti, 2018:72) adalah "substansi materi diakumulasi dari standar kompetensi atau kompetensi dasar yang tertuang dalam kurikulum, mudah dipahami, memiliki daya tarik, dan mudah dibaca."

Dalam memilih bahan ajar pendidik harus mempertimbangkan kriteria-kriteria yang meliputi “(1) relevansi (secara psikologis dan sosiologis), (2) komprehensif/keseimbangan” (Tim Pengembang MKDP Kurikulum dan Pembelajaran UPI, 2011:152). Berdasarkan kriteria penilaian bahan ajar berupa buku pelajaran setidaknya ada empat syarat terpenuhi bila sebuah bahan ajar dikatakan baik, yaitu "(1) cakupan materi atau isi sesuai dengan kurikulum, (2) penyajian materi memenuhi prinsip belajar, (3) bahasa dan keterbacaan baik, dan (4) format buku atau grafika menarik" (Puskurbuk d2012). Ketersediaan bahan ajar yang sesuai dengan standar kurikulum KKNI diperlukan oleh mahasiswa PGSD sebagai alat bantu pembelajaran dalam memahami dan membaca dari hal-hal yang dibaca (Chambliss dan Calfee dalam Suryaman, 2013:109).Sugiyono (2014) menyatakan bahwa pengembangan bahan ajar harus memerhatikan tiga prinsip, yaitu berpusat pada siswa, tingkat berpikir siswa, dan fleksibilitas.

Menurut Hanafy (2014: 66) Belajar dimaknai sebagai proses perubahan perilaku sebagai hasil interaksi individu dengan lingkungannya. Perubahan perilaku hasil belajar bersifat kontinyu, fungsional, positif, aktif dan terarah. Sedangkan pembelajaran adalah kegiatan yang berproses melalui tahapan perancangan, pelaksanaan dan evaluasi. Pembelajaran merupakan usaha yang dilakukan untuk memfasilitasi terjadinya proses belajar pada anak didik. Pembelajaran dimaknai pula sebagai interaksi peserta didik dengan pendidik dan sumber belajar dalam suatu lingkungan belajar. Dengan demikian efektifitas sebuah proses pembelajaran ditentukan oleh ketiga komponen tersebut. Menurut Pane (2017: 333) Belajar adalah proses perubahan tingkah laku dan ilmu pengetahuan. Proses belajar menjadi satu sistem dalam pembelajaran. Adapun sistem pembelajaran terdiri dari beberapa komponen yang saling berinteraksi satu sama lain, yaitu: guru, siswa, tujuan, materi, media, metode, dan evaluasi. Pembelajaran tidak akan dapat terlaksana dengan baik tanpa adanya interaksi antara komponen pembelajaran, maka diantara jenis komponen pembelajaran tersebut haruslah saling bekerja sama sehingga tercipta pembelajaran yang efisien.

Menurut Putry (2018: 42-43) karakter dapat dimaknai sebagai nilai dasar yang 


\section{Ninda, Rika. Pengembangan Bahan Ajar Mata...}

mempengaruhi pribadi seseorang, baik karena pengaruh hereditas maupun lingkungan, dan terwujud dalam sikap dan perilaku sehari-hari yang membedakannya dengan orang lain.

Menurut Raharjo (2010:17) memaknai pendidikan karakter sebagai suatu proses pendidikan secara holistis yang menghubungkan dimensi moral dengan ranah sosial dalam kehidupan peserta didik sebagai pondasi bagi terbentuknya generasi yang berkualitas yang mampu hidup mandiri dan memiliki prinsip suatu kebenaran yang dapat dipertanggungjawabkan.

Menurut Santoso (2019:51-53) Karakter mulia berarti individu memiliki pengetahuan tentang potensi dirinya, yang ditandai dengan nilai-nilai seperti reflektif, percaya diri, rasional, logis, kritis, analitis, kreatif dan inovatif, mandiri, hidup sehat, bertanggung jawab, cinta ilmu, sabar, berhati-hati, rela berkorban, pemberani, dapat dipercaya, jujur, menepati janji, adil, rendah hati, malu berbuat salah, pemaaf, berhati lembut, setia, bekerja keras, tekun, ulet/gigih, teliti, berinisiatif, berpikir positif, disiplin, antisipatif, inisiatif, visioner, bersahaja, bersemangat, dinamis, hemat/efisien, menghargai waktu, pengabdian/dedikatif, pengendalian diri, produktif, ramah, cinta keindahan (estetis), sportif, tabah, terbuka, tertib. Individu juga memiliki kesadaran untuk berbuat yang terbaik atau unggul, dan individu juga mampu bertindak sesuai potensi dan kesadarannya tersebut. Itulah karakter individu yang mulia yang dapat ditandai dengan nilai-nilai ketiga aspek tersebut sehingga dikatakan sebagai karakteristiknya.

Karakteristik Membangun Mahasiswa Yang Berkarakter, Profesional Dan Kompetitif Dengan Dijiwai Patriotisme, Kepeloporan Dan Kemandirian (adalah realisasi perkembangan positif sebagai individu (intelektual, emosional, sosial, etika, dan perilaku). Karakter adalah totalitas ciri-ciri pribadi yang melekat dan dapat diidentifikasi pada perilaku individu yang bersifat unik, yaitu membedakan individu yang satu dengan yang lainnya. Karena ciri-ciri karakter tersebut dapat diidentifikasi pada perilaku individu yang bersifat unik, maka karakter sangat dekat dengan kepribadian individu. Meskipun karakter setiap individu, karakteristik umum yang menjadi stereotif dari kelompok masyarakat dan bangsa dapat diidentifikasi sebagai karakter suatu komunitas tertentu atau bahkan dapat pula dipandang sebagai karakter suatu bangsa. Dengan demikian karakter berkaitan dengan kepribadian seseorang, sehingga dapat disebut orang berkarakter (a person of character) jika perilakunya sesuai dengan etika atau kaidah moral.

Tujuan dari artikel pengembangan modul ini yaitu 1) untuk menambah pemahaman mahasiswa mengenai Tri Ciri Tentara Pelajar yang mana akan dikembangkan di dalam mata kuliah belajar pembelajaran sehingga mahasiswa benar-benar menjiwai, memaknai dan bisa 


\section{Ninda, Rika. Pengembangan Bahan Ajar Mata...}

mengimplementasikan dalam kehidupan sehari-hari di kampus dan diluar kampus, 2) untuk mengetahui tingkat kelayakan bahan ajar yang dikembangkan.

\section{METODE}

Penelitian ini merupakan jenis penelitian pengembangan ( $R$ \& $D)$. Research and Development $(R \& D)$ adalah metode penelitian yang digunakan untuk menghasilkan produk tertentu, dan menguji efektivitas produk tersebut (Sugiyono, 2012). Produk yang dihasilkan dari penelitian ini berupa bahan ajar mata kuliah belajar dan pembelajaran berbasis tri ciri tentara pelajar pada modul. Dalam penyusunan modul ini menggunakan model pengembangan ADDIE yang terdiri dari Analysis, Design, Development, Implementation dan Evaluation. Namun, pada penelitan ini hanya dilakukan sampai tahap pengembangan, sedangkan tahap implementasi dan evaluasi dilakukan pada penelitian selanjutnya.

Adapun langkah-langkah yang dilakukan sebagai berikut:

a. Tahap Analysis (Analisis)

Pada tahapan ini dilakukan analisis kurikulum pada mata kuliah belajar dan pembelajaran dan tri ciri tentara pelajar

b. Tahap Design (Perencanaan)

Tahap perencanaan dilakukan berdasarkan hal-hal yang diperoleh dari tahap analisis. Kegiatan yang dilakukan pada tahap perencanaan meliputi: Penyusunan bahan ajar

1. Menyusun peta kebutuhan bahan ajar

2. Menentukan judul bahan akar

3. Penulisan bahan ajar

Penyusunan bahan ajar dapat dilakukan dengan langkah-langkah sebagai berikut:

- Perumusan kompetensi yang harus dikuasai

- Menentukan alat penilaian

- Penyusunan materi

4. Struktur bahan ajar

Secara umum modul harus memuat judul, petunjuk belajar (petunjukmahasiswa), kompetensi yang akan dicapai, informasi pendukung, tugas-tugas dan langkah kerja dan evaluasi/ penilaian.

c. Tahap Development (Pengembangan)

Tahap pengembangan meliputi kegiatan pembuatan bahan ajar. Setelah ditentukan kerangka penyusunan bahan ajar, langkah selanjutnya adalah menentukan produk bahan 


\section{Ninda, Rika. Pengembangan Bahan Ajar Mata...}

ajar. Bahan Ajar yang disusun memperhatikan syarat kualitas berikut; 1) Aspek Kelayakan Isi; 2) Aspek Kebahasaan 3) Aspek Penyajian dan 4) Aspek tri ciri tentara pelajar.

d. Tahap Implementation

Tahap implementasi dilakukan setelah produk yang dikembangkan selesai disusun. Pada tahap ini dilakukan uji coba yang terbatas yakni pada kelompok kecil yang terdiri dari 10 mahasiswa.

e. Tahap Evaluation

Adapun peta pengembangan modul belajar dan pembelajaran adalah sebagai berikut:
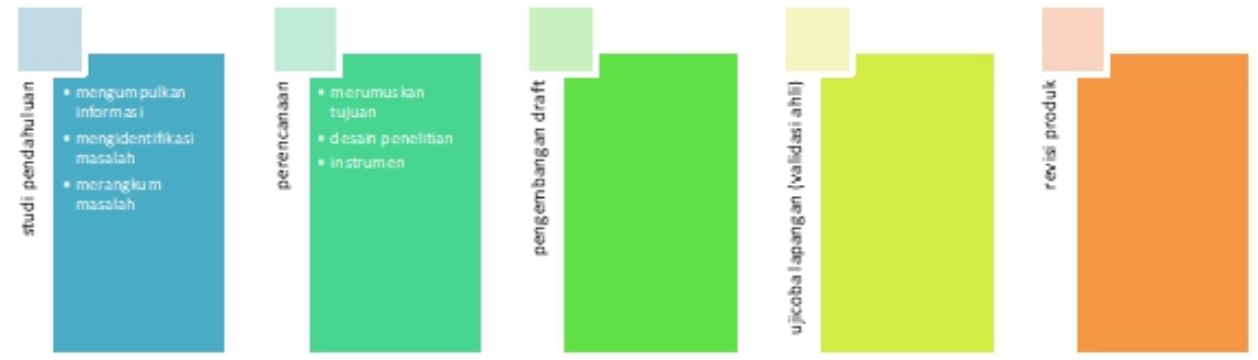

\section{Gambar 1. Peta pengembangan bahan ajar mata kuliah belajar pembelajaran berbasis Tri Ciri Tentara}

Instrumen yang digunakan dalam penelitian ini yaitu: 1) Lembar penilaian ahli; Lembar penilaian ini dinilai oleh 2 orang teman sejawat ahli materi dan pembelajaran, dan 2 orang teman sejawat ahli media dan ahli bahasa. Lembar penilaian ini untuk menentukan apakah bahan ajar layak digunakan tanpa revisi, dengan revisi atau tidak layak digunakan. Disamping itu, hasil penilaian ini digunakan sebagai acuan dalam perbaikan bahan ajar yang dikembangkan. Penilaian bahan ajar untuk ahli materi dan pembelajaran terdiri dari aspek kelayakan isi, aspek kebahasaan, dan aspek sajian. Sedangkan untuk ahli media penilaian produk meliputi aspek bahan ajar, aspek gambar/kegrafikan dan aspek tampilan. 2) Lembar evaluasi untuk siswa Lembar evaluasi ini digunakan untuk mengetahui tanggapan siswa berkaitan dengan penggunaan bahan ajar.

Dalam analisis data menggunaan data proses pengembangan produk berupa data proses pengembangan bahan ajar berupa data deskriptif, dicermati, disusun dan ditabulasi dan data kualitas produk yang dihasilkan berupa analisis lembar penilaian dan observasi kegiatan pembelajaran menggunakan produk bahan ajar.

\section{HASIL}


Ninda, Rika. Pengembangan Bahan Ajar Mata...

Tabel 1. Hasil Analisis Penilaian Ahli Materi dan Pembelajaran

\begin{tabular}{|c|c|c|c|c|}
\hline No & Aspek yang dinilai & Skor & Interval skor & $\begin{array}{c}\text { Kriteria } \\
\text { nilai }\end{array}$ \\
\hline 1 & Kelayakan isi & 66 & $\mathrm{X}>58,79$ & Sangat baik \\
\hline 2 & Kebahasaan & 58 & $47,59<\mathrm{X} \leq 58,79$ & Baik \\
\hline 3 & Sajian & 66 & $\mathrm{X}>58,79$ & Sangat baik \\
\hline 4 & $\begin{array}{c}\text { Berbasis Tri Ciri Tentara } \\
\text { Pelajar }\end{array}$ & 75 & $61,20<\mathrm{X} \leq 75,60$ & Baik \\
\hline
\end{tabular}

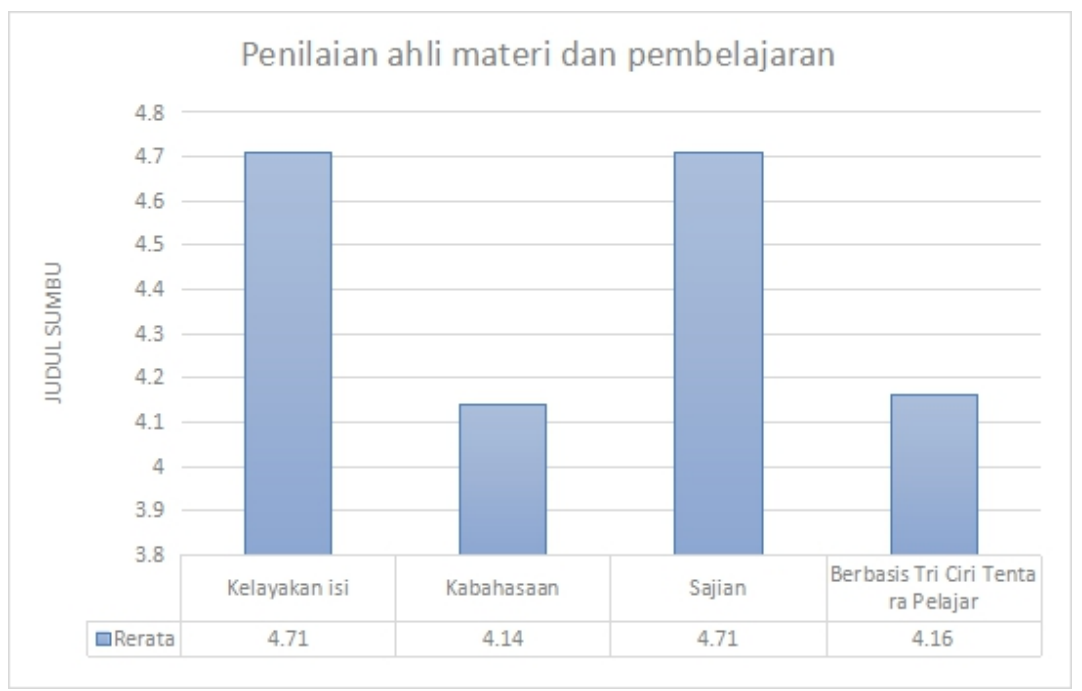

Gambar 2. Hasil Penilaian Ahli Materi dan Pembelajaran Tiap Aspek

Tabel 2. Hasil Analisis Penilaian Ahli Media

\begin{tabular}{|c|c|c|c|c|}
\hline No & Aspek yang dinilai & Skor & Interval skor & $\begin{array}{c}\text { Kriteria } \\
\text { nilai }\end{array}$ \\
\hline 1 & Bahan ajar modul & 37 & $\mathrm{X}>33,60$ & Sangat baik \\
\hline 2 & Gambar & 67 & $54,40<\mathrm{X} \leq 67,20$ & Baik \\
\hline 3 & Tampilan & 63 & $\mathrm{X}>58,74$ & Cukup \\
\hline
\end{tabular}


Ninda, Rika. Pengembangan Bahan Ajar Mata...

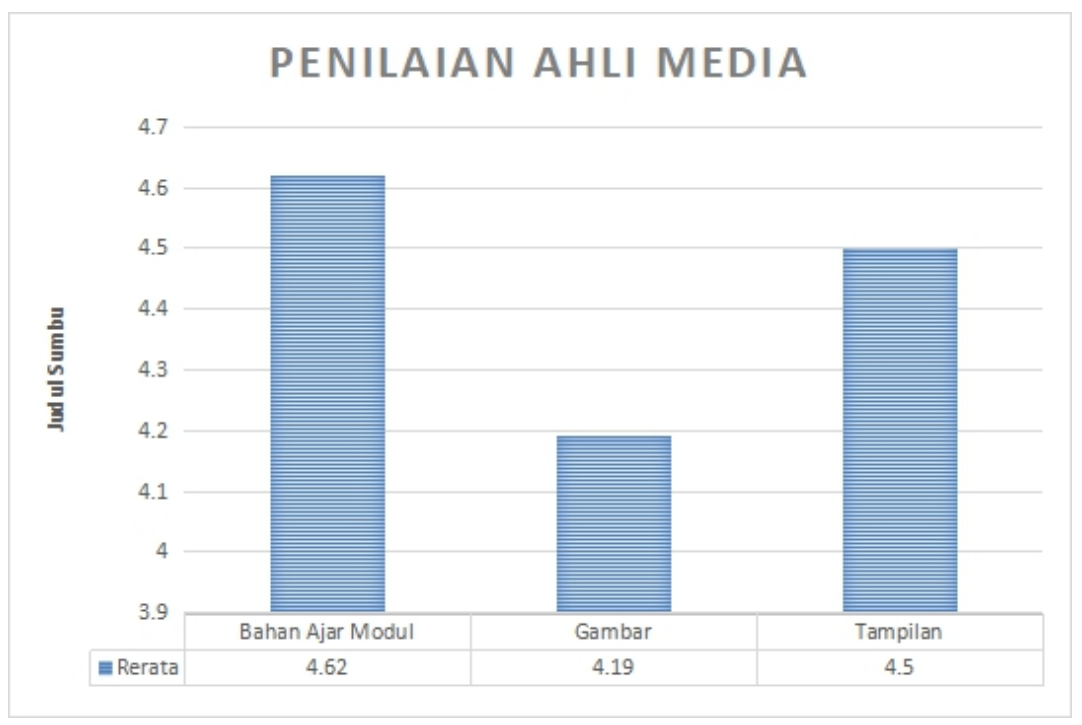

Gambar 3. Penilaian Ahli Media

\section{PEMBAHASAN}

Data hasil uji coba produk diperoleh dari berbagai sumber melalui lembar penilaian ahli materi dan pembelajaran, ahli media, dan uji coba terhadap 10 mahasiswa. Uji coba hanya dilakukan kepada kelompok kecil karena keterbatasan waktu.

Validasi ahli dimaksudkan untuk meminta persetujuan atau kesesuaian bahan ajar dengan kebutuhan, sehingga bahan ajar tersebut layak digunakan dalam proses pembelajaran. Sedangkan penilaian bertujuan untuk memperoleh masukkan dan saran dalam upaya perbaikan dan penyempurnaan bahan ajar. Penilaian tersebut dilihat dari beberapa aspek yang menentukan apakah bahan ajar tersebut layak untuk diujicobakan ke mahasiswa. Draf produk yang telah selesai disusun dilakukan penilaian oleh 2 orang teman sejawat sebagai ahli materi dan pembelajaran dengan latar belakang pendidikan S2 Teknologi Pendidikan dan S2 Pendidikan Dasar.

Aspek penilaian yang diajukan pada ahli materi meliputi aspek kelayakan isi, aspek kebahasaan, aspek sajian dan aspek lokal Tri Ciri Tentara Pelajar UTP Surakarta Data hasil penilaian 2 orang ahli materi dan pembelajaran secara keseluruhan diperoleh skor maksimalnya 300 , skor minimumnya $60, X_{i}=180$, dan $s b_{i}=40$. Berdasarkan keseluruhan penilaian produk oleh ahli materi dan pembelajaran diperoleh skor $X=265$, yang termasuk dalam kriteria nilai "Sangat Baik".

Berdasarkan penilaian ahli materi dan pembelajaran pada aspek kelayakan isi yang terdiri dari 7 indikator diperoleh skor 66, nilai maksimumnya 70, nilai minimumnya $14 X_{i}=42$ dan $s b_{i=9}$ 9,33 dengan rerata 4,71 dan kriteria nilai "Sangat Baik" . Pada aspek 


\section{Ninda, Rika. Pengembangan Bahan Ajar Mata...}

kebahasaan terdiri dari 7 indikator diperoleh skor 58, nilai maksimunnya 70, nilai

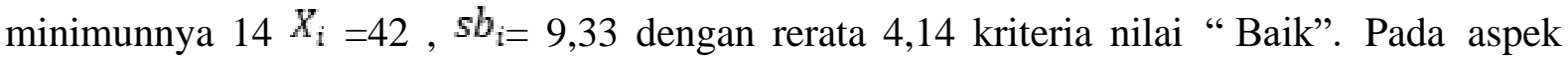
sajian terdiri dari 7 indikator penilaian diperoleh skor 66, nilai maksimunnya 70, nilai minimunnya $14 X_{i}=42, s b_{i=9,33}$ dengan rerata 4,71 kriteria nilai “ Sangat Baik". Sedangkan pada aspek Tri Ciri Tentara Pelajar terdiri dari 9 indikator penilaian diperoleh skor 75 , nilai maksimumnya 180 , nilai minimumnya $18 X_{i}=42, s b_{i} 9,33$ dengan rerata 4,16 kriteria "Baik".

Draf produk yang telah selesai disusun dilakukan penilaian oleh 2 orang teman sejawat sebagai ahli media. Aspek penilaian yang diajukan pada ahli media meliputi aspek bahan ajar modul, aspek gambar, dan aspek tampilan. Data hasil penilaian 2 orang ahli media secara keseluruhan diperoleh skor maksimalnya 190, skor minimumnya 38, dan $X_{i}=114 s b_{i}=25,33$. Berdasarkan keseluruhan penilaian produk oleh ahli media diperoleh skor $\mathrm{X}=167$, yang termasuk dalam kriteria nilai "Sangat Baik". Berdasarkan penilaian 2 orang ahli media, pada aspek bahan ajar modul yang terdiri dari 4 indikator diperoleh skor 37, nilai maksimumnya 40 , nilai minimumnya $8, X_{i}=24, s b_{i}=5,33$ dengan rerata 4,62 dan kriteria nilai "Sangat Baik". Pada aspek gambar terdiri dari 8 indikator. diperoleh skor 67, nilai maksimunnya 80 , nilai minimunnya $16, X_{i}=48 s b_{i}=10,67$ dengan rerata 4,19 kriteria nilai "Baik". Pada aspek tampilan terdiri dari 7 indikator penilaian diperoleh skor 63, nilai maksimumnya 70 , nilai minimunnya $14, X_{i}=42 s b_{i}=9,33$ dengan rerata 4,5 kriteria nilai "SangatBaik."

Berdasarkan penilaian ahli materi dalam pengembangan modul ini meliputi aspek isi meliputi aspek kelayakan isi, aspek kebahasaan, aspek sajian dan aspek lokal Tri Ciri Tentara Pelajar UTP Surakarta. Adapun kelayakan isi senada dengan apa yang Kinanti (2017; 342) dari BSNP terdiri dari 3 komponen yaitu kesesuaian KI dan KD, keakuratan materi dan materi pendukung pembelajaran. Adanya Materi pendukung pembelajaran tujuannya untuk melihat berapa besar tingkat kelayakan materi pendukung pembelajaran yang mendukung dalam buku teks. Fungsi dari materi pendukung pembelajaran dalam buku teks untuk melengkapi ulasan materi seperti ketersediaan soal, contoh, gambar, tugas-tugas yang merangsang keterampilan dan sebagainya. Hasil penelitian juga menunjukkan hasil yang hampir sama yaitu dalam penelitian Kinanti aspek kelayakan isi dinyatakan cukup layak sedangkan dalam penelitian ini mendapatkan kriteria sangat baik secara keseluruhan. Hal ini juga senada dengan penelitian Meiningsih (2019; 15-17) aspek isi yang dilakukan penilaian ahli materi serta aspek bahan ajar modul yang dinilai oleh ahli media mendapatkan penilaian dengan kriteria layak. Aspek yang dinilai pada aspek sajian sama yaitu meliputi sistematika 


\section{Ninda, Rika. Pengembangan Bahan Ajar Mata...}

penyajian, keruntutan penyajian, glosarium dan daftar pustaka mendapatkan prosentase $77,08 \%$ yang berarti perolehan skor cukup, sehingga penyajian materi disajikan dengan konsep dari yang mudah ke yang sukar, dari yang sederhana ke kompleks, dari yang dikenal ke yang belum dikenal. Sedangkan aspek kebahasaan yang dinilai meliputi keterbacaan, kesesuaian dengan kaidah Bahasa Indonesia, kebakuan istilah, penggunaan istilah, simbol/lambang dan nama istilah dengan prosentase $63,89 \%$ yang berarti modul yang digunakaan menggunakan bahasa yang menarik, mudah dipahami dan tidak menimbulkan multitafsir.

Penelitian yang sama yang juga mendapatkan skor yang sangat bagus senada dengan penelitian Wulandari $(2017$; 171) bahwa hasil validasi buku ajar oleh ahli materi dan media berada pada kategori layak dengan predikat sangat bagus. Materi; kelayakan isi 91,07\%, kelayakan penyajian 90,625\% dan $100 \%$ untuk aspek media). Pada aspek materi bagian kelayakan isi, buku ajar sastra lama juga telah memenuhi kesesuaian materi dengan capaian pembelajaran mata kuliah, keakuratan materi, kemutakhiran materi dan mendorong keingintahuan mahasiswa. Aspek materi bagian kelayakan penyajian, sangat baik karena telah memiliki teknik penyajian, pendukung penyajian, serta koherensi dan keruntutan yang bernilai baik. Berdasarkan aspek media (buku ajar) buku ajar sastra lama dinilai sangat layak aspek yang dinilai sama dengan peneliti yaitu dilihat dari aspek desain sampul buku, desain layout isi buku, kelayakan penulisan, kelayakan kebahasaan.Hasil penilaian ahli materi dan media yang layak dan memadai diharapkan mampu untuk memotivasi mahasiswa mempelajari isi buku. Hal ini senada dengan yang disampaikan Adalikwu, S.A dan lorkpilgh (2013) menjelaskan bahwa bahan ajar memiliki peran sebagai fasilitator pendidik dengan peserta didik serta untuk mengembangkan motivasi peserta didik pada proses kegiatan pembelajaran.

Hal tersebut menuntut terciptanya pembelajaran konstruktivisme, yaitu pembelajaran yang bertujuan membantu mahasiswa mengeksplorasi topik dan menggeneralisasi pengetahuan. Kemampuan mahasiswa untuk mengeksplorasi topik dan menggeneralisasi pengetahuan perlu mengupayakan bahan ajar kreatif. Pernyataan tersebut selaras dengan hasil penelitian Suwiwa, dkk bahwa peristiwa pembelajaran perlu diintegrasikan dalam bahan ajar, peristiwa pembelajaran yang dimaksud adalah menarik perhatian mahasiswa, penyampaian tujuan, mengaktifkan pengetahuan awal, penyajian isi, memberi petunjuk belajar, memberi latihan atau unjuk kerja, memberi umpan balik, melakukan penilaian serta meningkatkan transfer dan retensi pengetahuan (Suwiwa, I.G., 2014). Oleh karena itu, pembelajaran belajar dan pembelajaran berbasis Tri Ciri Tentara Pelajar memerlukan bahan ajar yang dapat 
Ninda, Rika. Pengembangan Bahan Ajar Mata...

membantu mahasiswa memahami materi bahan ajar tersebut.

\section{SIMPULAN}

1. Pengembangan bahan ajar mata kuliah belajar dan pembelajaran berbasis Tri Ciri Tentara Pelajar pada mahasiswa UTP Surakarta disusun dengan menerapkan model pengembangan ADDIE (Analysis, Design, Development, Implementation, \& Evaluation). Langkah analisis meliputi analisis kurikulum, analisis karakteristik siswa dan analisis instruksional. Tahap perancangan dilaksanakan dengan penyusunan bahan ajar. Pada tahap pengembangan dilaksanakan pengembangan draf bahan ajar dengan aspek-aspek yang telah ditentukan, dilanjutkan dengan validasi ahli. Hasil validasi dari ahli media maupun ahli materi dan pembelajaran menunjukkan tingkat kelayakan yang sangat baik.

2. Berdasarkan keseluruhan penilaian produk oleh ahli materi dan pembelajaran diperoleh skor $X=265$, yang termasuk dalam kriteria nilai “ Sangat Baik". Sedangkan keseluruhan penilaian produk oleh ahli media diperoleh skor $X=167$, yang termasuk dalam kriteria nilai "Sangat Baik".

\section{UCAPAN TERIMAKASIH}

Peneliti mengucapkan terima kasih kepada Universitas Tunas Pembangunan Surakarta (UTP Surakarta) sebagai penyandang dana, terima kasih juga kepada mahasiswa UTP Surakarta atas kerjasamanya dalam proses penelitian dan berbagai pihak yang telah membantu penelitian sampai selesai.

\section{DAFTAR RUJUKAN}

Adalikwu, S.A. dan lorkpilgh, I.T. (2013). The Influence of Instructional Materials on Academic Performance of Senior Secondary School Students in Chemistry in Cross River State. Global Journal of Educational Research, 20 (1), 39-45.

Arsanti, Meilan. (2018). Pengembangan Bahan Ajar Mata Kuliah Penulisan Kreatif Bermuatan Nilai-Nilai Pendidikan Karakter Religius Bagi Mahasiswa Prodi Pbsi, Fkip, Unissula. Jurnal Kredo, 1 (2), 69-88.

Gultom, S. (2012). Pedoman Penulisan Buku Ajar Peningkatan Kompetensi Pendidik Pendidikan Nonformal. Jakarta: Kemendikbud.

Hanafy, Muh Sain. (2014). Konsep Belajar dan Pembelajaran. Jurnal Lentera Pendidikan, 17 (1), 66-79.

Kinanti, L.P., \& Sudirman. (2017). Analisis Kelayakan Isi Materi Dari Komponen 
Ninda, Rika. Pengembangan Bahan Ajar Mata...

Materi Pendukung Pembelajaran Dalam Buku Teks Mata Pelajaran Sosiologi

Kelas XI SMA Negeri Di Kota Bandung. Jurnal SOSIETAS ,7 (1), 341-345.

Kurniawati, Tri, dkk. (2015). Pengembangan Draft Bahan Ajar Pada Mata Kuliah

Basic Reading Program Studi Bahasa Inggris. Jurnal Pendidikan Bahasa, 2 (2), 281-293.

Meiningsih, D., Alimah, S., Yustinus, U.A. (2019). Majalah It Fly V.A Alternatif

Pilihan Sumber Belajar Biologi. Jurnal PHENOMENON, 9 (1), 10-20.

Noviyanti \& Gading G. (2020). Model Pengembangan ADDIE dalam penyusunan

Buku Ajar Administrasi Keuangan. Jurnal Ilmiah Manajemen Publik dan Kebijakan Sosial, 4 (2), 100-120.

Pane, Aprida \& Muhammad Darwis Dasopang. 2017. Belajar dan Pembelajaran. FITRAH: Jurnal Kajian Ilmu-ilmu Keislaman, 3 (2), 333-352.

Prasetiyo, N. A \& Perwiraningtyas, Pertiwi. 2017. Pengembangan Buku Ajar Berbasis Lingkungan Hidup Pada Matakuliah Biologi di Universitas Tribhuwana Tunggadewi. Jurnal Pendidikan Biologi Indonesia, 3 (1), 19-27.

Pusat Kurikulum dan Perbukuan. (2012). Penilaian Buku Teks Pelajaran. http://puskurbuk.net/web/penilian-buku-teks-pelajaran.html (Diunduh 10 Februari 2021).

Putry, Raihan. (2018). Nilai Pendidikan Karakter Anak di Sekolah Perspektif Kemendiknas. Gender Equality: Internasional Journal of Child and Gender Studies. 4 (1), 39-54.

Raharjo, Sabar Budi. (2011). Pendidikan Karakter sebagai Upaya Menciptakan Akhlak Mulia. Jurnal Pendidikan dan Kebudayaan. 16 (3), 229-238.

Santoso, Nuruddin Priya Budi. (2019). Membangun Insan Olahraga Yang Berkarakter, Profesional Dan Kompetitif Dengan Dijiwai Patriotisme,Kepeloporan Dan Kemandirian. Jurnal Ilmiah Mitra Swara Ganesha, 6 (1), 47-57.

Sihotang, C., \& Sibuea, A. M. (2015). Pengembangan Buku Ajar Berbasis Kontekstual dengan Tema "Sehat Itu Penting”. Jurnal TeknologiInformasi dan Komunikasi dalam Pendidikan, 2 (2).

Sugiyono. (2012). Metode Penelitian Pendidikan Pendekatan Kuantitatif, Kualitatif, dan $R \& D$. Bandung: Alfabeta.

Sugiyono, E. I. (2014). Pengembangan Bahan Ajar Menyimak Berbasis Multimedia Interaktif dalam Model Belajar Mandiri untuk Sekolah Menengah Pertama. Seloka: Jurnal Pendidikan Bahasa dan Sastra Indonesia, 3(2), 83-89. 
Ninda, Rika. Pengembangan Bahan Ajar Mata...

Suryaman, dkk. (2013). Pengembangan Model Buku Ajar Sejarah Sastra Indonesia Modern Berprespektif Gender. Jurnal Ilmiah Model Pengembangan ADDIE Dalam Penyusunan Buku Ajar, 12 (1), 106-118.

Suwiwa, I.G., dkk. (2014). Pengembangan Multimedia Integratif Pembelajaran Pada Mata Kuliah Teori dan Praktik Pencak Silat. E-Journal Program Pascasarjana Universitas Pendidikan Ghanesa, Program Studi Teknologi Pembelajaran 4 (1), 1-12.

Tim Pengembang MKDP Kurikulum dan Pembelajaran UPI. 2011. Kurikulum dan Pembelajaran. Bandung: UPI.

Wulandari, Y., \& Purwanto, W. E. (2017). Kelayakan Aspek Materi dan Media Dalam Pengembangan Buku Ajar Sastra Lama. Jurnal Penelitian Pendidikan Bahasa dan Sastra Indonesia V3 (i2), 162-172. 